\title{
HUMAN LEUKOCYTE ANTIGENS CLASS II ALLELES AFFECTING THE RESPONSE TO 5-7 YEAR ANTIRETROVIRAL THERAPY IN A LATVIAN COHORT
}

\author{
Vladislavs Jasinskis ${ }^{1, \#}$, Oksana Koḷesova ${ }^{1}$, Aleksandrs Koḷesovs ${ }^{2}$, Baiba Rozentāle ${ }^{3}$, \\ Inga Ažina ${ }^{3}$, Ksenija Kramiča ${ }^{4}$, Ludmila Vỉksna ${ }^{5}$, and Jeḷena Eglïte ${ }^{1}$ \\ 1 Joint Laboratory of Clinical Immunology and Immunogenetics, Rīga Stradiṇš University, 5 Rātsupītes Str., Rīga, LV-1067, LATVIA \\ ${ }^{2}$ Faculty of Education, Psychology and Art, University of Latvia, 1 Imantas $7^{\text {th }}$ line, Rĩga, LV-1083, LATVIA \\ ${ }^{3}$ Latvian Centre of Infectious Diseases, Rīga Eastern Clinical University Hospital, 3 Linezera Str., Rīga, LV-1006, LATVIA \\ ${ }^{4}$ Doctoral Studies, Rīga Stradinš University, 16 Dzirciema Str., Rĩga, LV-1007, LATVIA \\ ${ }^{5}$ Department of Infectology and Dermatology, Rīga Stradiṇš University, 3 Linezera Str., Rīga, LV-1006, LATVIA \\ \# Corresponding author, mikrogen@inbox.lv
}

Contributed by Ludmila Vikksna

\begin{abstract}
Antiretroviral therapy (ART) aims at suppressing viral replication and strengthening immune system in patients with HIV-1. Human Leukocyte Antigens (HLA) are among factors responsible for effectiveness of ART. The aim of this study was to determine the effect of HLA Class II alleles on the response to long-time $A R T$, assessed by a change in $C D 4^{+} T$-cell count in relation to viral load. The sample included 69 patients (17 females and 52 males) aged 20 to 50 with HIV-1 infection, who were undergoing ART in the Latvian Centre of Infectious Diseases. The median period of observation was 5.7 years. CD4 $4^{+} T$-cell count and viral load were analysed at the baseline and end of the period of observation. HLA typing was performed by polymerase chain reaction with low resolution sequence specific primers. Multiple hierarchical linear regression analysis confirmed that an increase in HIV-1 viral load was associated with a decrease in the level of CD4 ${ }^{+} T_{-}$ cell count. In addition, $H L A-D R B 1^{*} 04$ and $H L A-D Q B 1^{*} 06: 01$ alleles contributed negatively to the level of $C D 4^{+} T$-cell count.
\end{abstract}

Key words: HLA Class II, HIV-1, ART, CD4 $4^{+} T$ cells.

\section{INTRODUCTION}

HIV is a global public health problem. In 2016, more than a million people died from HIV-associated causes around the world. The aim of antiretroviral therapy is to suppress viral replication, strengthen the individual's immune system, and regain the capacity to resist infections. In accordance to World Health Organization (WHO) recommendations, antiretroviral therapy (ART) should be initiated in all people living with HIV, regardless of WHO clinical stage and $\mathrm{CD}^{+}$T-cell count (Anonymous, 2016a). Unfortunately, failure is not a rare outcome of ART, which remains the subject of empirical studies (Boettiger et al., 2014; Patrikar et al., 2017).
ART failure is associated with a variety of factors: poor adherence to medication, missed visits, a higher baseline viral load, a lower baseline $\mathrm{CD} 4^{+} \mathrm{T}$-cell count, a low absolute neutrophil count, low BMI, and opportunistic infections (Lucas et al., 1999; Lundgren et al., 2002; Robbins et al., 2007; Patrikar et al., 2017). Treatment failure can be assessed through monitoring of viral load, $\mathrm{CD}^{+} \mathrm{T}$-cell count, and a new or recurrent clinical event. In accordance with WHO recommendations (Anonymous, 2016a), viral load monitoring is preferred for confirming treatment failure. However, based on a negative relationship between viral load and $\mathrm{CD}^{+}{ }^{+}$T-cell count (Pantaleo and Fauci, 1996), $\mathrm{CD} 4{ }^{+} \mathrm{T}$-cell response has been preferred in monitoring the success of ART in resource-limited settings (e.g., Keiser et 
al., 2009; Odafe et al., 2012; Montarroyos et al., 2014; Gezie et al., 2017).

Studies have also shown that a response to ART is related to allelic variants of different genes (Haas et al., 2005; Zhu et al., 2005). One of the groups of these genes is the Human Leukocyte Antigens (HLA), which are essential in the regulation of immune response. Previous studies demonstrated that HLA Class I and Class II alleles affect susceptibility to HIV infection and development time of AIDS (Saah et al., 1998; Keet et al., 1999), viral control in ART-naive patients (Jugl et al., 2011; Ranasinghe et al., 2013), and adverse reactions during ART (Mallal et al., 2002; Pavlos et al., 2012). In ART-naive patients, The HLA-DRB1*03:01 allele (significantly) and HLA-DRB1*04:04, 01:01, 15:01, and 08:01 alleles (with marginal significance) were shown to be associated with high viremia (Ranasinghe et al., 2013). At the same time, information about effect of HLA genes on ART effectiveness is limited. In early-treated patients, the HLA-DRB $1 * 13 /$ HLA-DQB $1 * 06$ haplotype had a protective effect on virological and immunological responses (Malhotra et al., 2001).

The goal of the present study was to determine the effect of HLA Class II alleles on response to long-term ART by estimating change in $\mathrm{CD}^{+}{ }^{+} \mathrm{T}$ cells in relation to viral load. We expected that alleles associated with high viremia in ARTnaive patients can negatively affect the progress in ART (Ranasinghe et al., 2013), while protective alleles can positively affect ART (Malhotra et al., 2001).

\section{MATERIALS AND METHODS}

The study was retrospective, approved by the Central Medical Ethics Committee, Rīga, Latvia. The sample included 69 patients (17 females and 52 males) aged 20 to 50 (mean age was $32.68, \mathrm{SD}=8.38$ ) with HIV-1 infection, who were undergoing ART in the Latvian Centre of Infectious Diseases (currently Latvian Centre of Infectious Diseases of Rīga Eastern Clinical University Hospital) in the period from 1998 till 2012. Inclusion criteria were: confirmed HIV-1 infection, received ART in accordance with recommendations, and monitoring of $\mathrm{CD}^{+}{ }^{+} \mathrm{T}$-cell count and viral load. The diagnosis of HIV-1 infection was confirmed by detection of specific antibodies and HIV-1 antigen (ELISA) and specific antibodies to HIV-1, using the Immunoblot and Western blot methods.

The median period of observations in the study was 5.7 years (from 4 to 7 years). All patients received ART in accordance to national recommendations: two nucleoside reverse transcriptase inhibitors (NRTI) combined with one protease inhibitor (PI) or one non-nucleoside reverse transcriptase inhibitor (NNRTI).

Information about patient age, sex, treatment regiment, and compliance was collected from medical documentation. In addition, the documentation included data on viral load and $\mathrm{CD} 4^{+} \mathrm{T}$-cell count at the beginning and end of the observa- tion period. Both investigations were performed at the Latvian Centre of Infectious Diseases. Viral load testing was performed by the polymerase chain reaction. $\mathrm{CD}^{+}{ }^{+} \mathrm{T}$-cell count was determined by flow cytometry.

The investigation of HLA class II genotype of each patient was performed in the Joint Laboratory of Clinical Immunology and Immunogenetics of Rīga Stradiňš University. Peripheral blood samples $(5 \mathrm{ml})$ were collected in EDTA containing tubes and stored at $-20{ }^{\circ} \mathrm{C}$. The QIAamp® DNA Blood Kit (QIAGEN, Germany) was used for human DNA extraction according to manufacturer's instruction (Anonymous, 2016b). DNA amplification was performed by polymerase chain reaction (PCR) with low resolution sequence specific primers (DNA-Technology, Russia) according to manufacturer's instructions (Anonymous, 2018). Each kit contained an internal control for evaluation of PCR quality and positive control. HLA typing included identification of HLA-DRB1* alleles (01 to 18), HLADQA1* alleles (01:01, 01:02; 01:03; 01:04, 02:01; 03:01; 04:01, 05:01, 06:01), and HLA-DQB1* alleles (02:0102:02; 03:01-04; 04:01-04:02; 05:01-04; 05:02-03; 06:01; 06:02-08). Amplification was performed using a Real-Time PCR Thermal Cycler "DT-Lite" with four channels and 48 wells (DNA-Technology, Russia). The reaction mixture was subjected to 35 amplification cycles, each consisting of denaturation at $94{ }^{\circ} \mathrm{C}(60 \mathrm{~s})$, followed by one cycle, annealing at $94{ }^{\circ} \mathrm{C}(20 \mathrm{~s}), 67{ }^{\circ} \mathrm{C}(2 \mathrm{~s})$ followed by seven cycles and extension at $93{ }^{\circ} \mathrm{C}(5 \mathrm{~s}), 65^{\circ} \mathrm{C}(4 \mathrm{~s})$, with a final extension instep with 35 cycles.

The statistical analysis was performed using IBM SPSS Statistics for Windows, Version 22.0. Normality of distribution was assessed using the Shapiro-Wilk and KolmogorovSmirnov tests with Lilliefors significance correction. Significance of differences in values at two difference times was determined using the Wilcoxon test. The relationship between parameters was estimated using Pearson productmoment correlation coefficient. A multiple hierarchical linear regression analysis combined a standard regression for a change in $\mathrm{CD}^{+}$T-cell count predicted by a change in the viral load and a statistical regression for the assessment of alleles as additional predictors.

\section{RESULTS}

A quantitative analysis of the alleles was performed. Table 1 summarises the observed allele frequencies.

Table 2 presents descriptive statistics for $\mathrm{CD}^{+} \mathrm{T}$-cell count, HIV-1 viral load, and viral load (log) at the start and end point of the observation. The Wilcoxon test revealed no significant difference between the two times in $\mathrm{CD} 4^{+}$ T-cell count and viral load.

A significant negative relationship was found between $\mathrm{CD} 4^{+} \mathrm{T}$-cell count and viral load viral load ( $(\mathrm{r}=-0.41, p<$ $0.01, \mathrm{n}=67)$. 
Table 1

DISTRIBUTION OF HLA CLASS II ALLELES IN PATIENTS WITH HIV-1 INFECTION $(\mathrm{n}=69)$

\begin{tabular}{l|c|c|c|c|c}
\hline \multicolumn{2}{c|}{ HLA-DRB1 } & \multicolumn{2}{c|}{ HLA-DQ1 } & \multicolumn{2}{c}{ HLA-DQB1 } \\
\hline alleles & $\begin{array}{c}\text { frequency } \\
(\% \text { of } \\
\text { patients })\end{array}$ & alleles & $\begin{array}{c}\text { frequency } \\
(\% \text { of } \\
\text { patients })\end{array}$ & alleles & $\begin{array}{c}\text { frequency } \\
(\% \text { of } \\
\text { patients })\end{array}$ \\
\hline$* 01$ & $26(37.7)$ & $* 01: 01$ & $17(24.6)$ & $* 02: 01-02$ & $20(29.0)$ \\
$* 04$ & $7(10.1)$ & $* 01: 02$ & $22(31.9)$ & $* 03: 01$ & $30(43.5)$ \\
$* 07$ & $12(17.4)$ & $* 01: 03$ & $11(15.9)$ & $* 03: 02$ & $10(14.5)$ \\
$* 08$ & $5(7.2)$ & $* 01: 04$ & $1(1.4)$ & $* 03: 03$ & $13(18.8)$ \\
$* 09$ & $3(4.3)$ & $* 02: 01$ & $17(24.6)$ & $* 03: 04$ & $1(1.4)$ \\
$* 10$ & $2(2.9)$ & $* 03: 01$ & $22(31.9)$ & $* 04: 01-02$ & $3(4.3)$ \\
$* 11 / 12$ & $28(40.6)$ & $* 04: 01$ & $3(4.3)$ & $* 05: 01$ & $18(26.1)$ \\
$* 13 / 14$ & $16(23.2)$ & $* 05: 01$ & $39(56.5)$ & $* 05: 02$ & $7(10.1)$ \\
$* 15 / 16$ & $23(33.3)$ & - & - & $* 05: 03$ & $1(1.4)$ \\
$* 17 / 18$ & $12(17.4)$ & - & - & $* 06: 01$ & $2(2.9)$ \\
- & - & - & - & $* 06: 02-08$ & $20(29.0)$
\end{tabular}

A multiple hierarchical linear regression was applied to determine predictors of a change in the $\mathrm{CD} 4^{+} \mathrm{T}$-cell count. The regression model combined a standard regression for log viral load at the first step and a statistical regression for HLA Class II alleles at the next steps. In addition, age, sex, and time length between first and second time points were controlled during the analysis. Table 3 shows the results at each step. The variance inflation factor (VIF) varied from 1.00 to 1.17 and indicated acceptable level of covariance among the predictors. The results confirmed increase of HIV-1 viral load as a significant predictor for an increase in for a decrease in $\mathrm{CD}^{+} \mathrm{T}$-cell count. In addition, HLADRB $1 * 04$ and DQB $1 * 06: 01$ alleles demonstrated a negative contribution to the change of $\mathrm{CD} 4^{+} \mathrm{T}$-cell count. No allele contributed positively to $\mathrm{CD} 4^{+} \mathrm{T}$-cell count. It should be also noted that age, sex, and observed length of the interval between two measures ( 5 to 7 years) were not significant predictors.

$\mathrm{CD}^{+}{ }^{+} \mathrm{T}$ CELL COUNT AND HIV-1 VIRAL LOAD AT THE BEGINNING $\left(\mathrm{T}_{0}\right)$ AND THE END $\left(\mathrm{T}_{1}\right)$ OF THE STUDY $(\mathrm{n}=69)$

\begin{tabular}{|c|c|c|c|c|c|}
\hline \multirow[t]{2}{*}{ Parameter } & \multirow{2}{*}{$\frac{\mathrm{T}_{0}}{\mathrm{M} \pm \mathrm{SD}}$} & \multirow{2}{*}{$\frac{\mathrm{T}_{1}}{\mathrm{M} \pm \mathrm{SD}}$} & \multirow{2}{*}{$\begin{array}{c}\text { Difference } \\
\mathrm{M} \pm \mathrm{SD}\end{array}$} & \multicolumn{2}{|c|}{ Wilcoxon test } \\
\hline & & & & $\mathrm{z}$ & $\mathrm{p}$ \\
\hline $\mathrm{CD} 4^{+}$, cells $/ \mu \mathrm{l}$ & $468.90 \pm 268.27$ & $420.28 \pm 290.03$ & $-48.62 \pm 335.20$ & -1.47 & 0.141 \\
\hline VL, copies/ml & $1.13 \cdot 10^{5} \pm 2.89 \cdot 10^{5}$ & $0.91 \cdot 10^{5} \pm 1.96 \cdot 10^{5}$ & $-0.22 \cdot 10^{5} \pm 3.51 \cdot 10^{5}$ & -0.18 & 0.861 \\
\hline $\lg (\mathrm{VL})$ & $3.80 \pm 1.19$ & $3.67 \pm 1.28$ & $-0.13 \pm 1.65$ & -0.48 & 0.635 \\
\hline
\end{tabular}

M, mean; SD, standard deviation; VL, HIV-1 viral load; lg, decimal logarithm.

A MULTIPLE HIERARCHICAL LINEAR REGRESSION ON A CHANGE IN THE LEVEL OF CD4 ${ }^{+}$T CELL COUNT $^{\circ}$

\begin{tabular}{|c|c|c|c|}
\hline Predictors & $B$ & $S E B$ & $\overline{\mathrm{A}}$ \\
\hline \multicolumn{4}{|c|}{ Step 1: $F(4,64)=3.68, p<0.01 ; R^{2}=0.19 ;$ adjusted $R^{2}=0.14$} \\
\hline Constant & -256.28 & 347.29 & \\
\hline Age & 5.13 & 4.79 & 0.13 \\
\hline Sex & 47.85 & 91.22 & 0.06 \\
\hline Interval between measures & 0.00 & 0.15 & 0.00 \\
\hline Change in $\lg (\mathrm{VL})$ & -72.54 & 24.25 & $-0.36^{* *}$ \\
\hline \multicolumn{4}{|c|}{ Step 2: $F(5,63)=5.33, p<0.001 ; R^{2}=0.30 ;$ adjusted $R^{2}=0.24 ; \Delta R^{2}=0.11$. } \\
\hline Constant & -190.16 & 326.08 & \\
\hline Age & 3.51 & 4.52 & 0.09 \\
\hline Sex & 47.86 & 85.48 & 0.06 \\
\hline Interval between measures & 0.01 & 0.14 & 0.01 \\
\hline Change in $\lg (\mathrm{VL})$ & -72.53 & 22.72 & $-0.36^{* * *}$ \\
\hline$\underline{\text { HLA-DRB } 1 * 04}$ & -369.01 & 117.29 & $-0.34^{* *}$ \\
\hline \multicolumn{4}{|c|}{ Step 3: $F(6,62)=5.69, p<0.001 ; R^{2}=0.36 ;$ adjusted $R^{2}=0.29 ; \Delta R^{2}=0.06$. } \\
\hline Constant & -7.52 & 281.44 & \\
\hline Age & 1.91 & 4.42 & 0.05 \\
\hline Sex & 64.96 & 82.86 & 0.08 \\
\hline Interval between measures & -0.01 & 0.14 & -0.01 \\
\hline Change in $\lg (\mathrm{VL})$ & -82.62 & 22.35 & $-0.41^{* * *}$ \\
\hline HLA-DRB1*04 & -387.32 & 113.53 & $-0.35^{* *}$ \\
\hline HLA-DQB1*06:01 & -492.57 & 208.94 & $-0.25^{*}$ \\
\hline
\end{tabular}

$\overline{{ }^{* * *} p<0.001 .{ }^{* *} p}<0.01 .{ }^{*} p<0.05 . \lg (\mathrm{VL})$, decimal logarithm of the viral load. 
The following analysis demonstrated that haplotypes associated with revealed alleles are rarely presented. HLADRB $1 * 04 /$ HLA-DQA $1 * 01: 04$ and HLA-DRB $1 * 06 /$ HLADQB1*06:01 were presented once. The haplotype HLADQA1*01:02/HLA-DQB106:01 was observed two times, and HLA-DRB 1*04/HLA-DQB1*03:02 was identified three times. Adding them to the analysis demonstrated no significant change in the predicted model.

\section{DISCUSSION}

In addition to the well-known association between $\mathrm{CD} 4^{+}$ T-cell count and HIV-1 viral load (Pantaleo and Fauci, 1996), the present study demonstrated effect of HLA Class II alleles on the observed change in $\mathrm{CD}^{+}{ }^{+} \mathrm{T}$-cell count. Among the alleles under investigation, HLA-DRB1*04 and HLA-DQB1*06:01 demonstrated statistically significant association with decreasing $\mathrm{CD} 4^{+}$T-cell count over the ART period of 5 to 7 years. Taking into account that $\mathrm{CD} 4^{+} \mathrm{T}$-cell count is one of the key indicators of the HIV disease progression (Mellors et al., 1997; Langford et al., 2007), we conclude that these alleles had a negative impact on ART in the present cohort.

The observed negative impact of the HLA-DRB $1 * 04$ genotype on the course of HIV-1 infection during ART is in accordance with previous studies (Saah et al., 1998; Ranasinghe et al., 2013), which showed that the HLA-DRB1*04 genotype was a HLA marker with adverse effect in HIV-1 patients.

The present study showed also negative effect of the HLADQB1*06:01 allele on the HIV-1 course during long-term ART. This is in contrast with a study (Malhotra et al., 2001) that demonstrated a protective effect of HLA-DQB1*06:01 allele within the HLA-DRB1*13/HLA-DQB1*06 haplotype. Patients who inherited this haplotype had a greater likelihood of effectively controlling HIV-1 replication during 18 month-long ART (Malhotra et al., 2001). A possible explanation of this effect can be associated with the time interval of therapy and the cohort involved in our study.

It should be noted that the role of HLA Class II alleles in therapy was investigated for different pathologies. In patients with multiple sclerosis receiving long-term interferon beta therapy, 04:01 and 04:08 alleles of HLA-DRB1*04 allelic group were associated with the production of antibodies against interferon beta therapy leading to a less effective interferon beta treatment (Buck et al., 2011). In addition, the HLA-DRB1*04 allelic group had a role in predisposition to the most severe form of rheumatoid arthritis (Zanelli et al., 2002; Balandraud et al., 2013) and more rapid disease progression (Kapitiny et al., 2008). HLA-DRB1*04 alleles, particularly homozygosity for HLA-DRB1*04, were univariate predictors of radiographic progression (Goronzy et al., 2004). Therefore, the HLA-DRB $1 * 04$ allelic group is a risk marker for a variety of pathologies. This conclusion indicates the direction for the further study on multiple immu- nological effects of this allelic group in therapy, including the level of $\mathrm{CD}^{+} \mathrm{T}$-cell change.

It should be noted that the present study had some limitations. The number of patients under observation was relatively low, which was due to socioeconomic difficulties limiting inclusion and following patients during the study. However, it allowed and provide an initial statistical assessment. Taking into account the broad temporal interval of observations in this study, a more coherent sample should be preferred for the further investigation of long-time ART. A stronger control of virological, immunological, and clinical markers of treatment failure is needed for a more detailed description of change dynamics.

It can be concluded that, as host genetic factors, HLA Class II alleles can affect long-time ART and disease progression. Our study demonstrated that HLA-DRB1*04 and HLADQB1*06:01 alleles are risk markers in the Latvian cohort of HIV-1 patients undergoing long-time ART. Information regarding patient's HLA Class II genotype might be helpful to guide ART in patients with HIV-1 infection.

\section{REFERENCES}

Anonymous (2016a). Consolidated guidelines on the use of antiretroviral drugs for treating and preventing HIV infection: Recommendations for a public health approach. $2^{\text {nd }}$ edn. World Health Organization, Geneva. Available from: http://apps.who.int/iris/bitstream/handle/10665/208825/ 9789241549684_eng.pdf?sequence=1 (accessed 14 September 2018).

Anonymous (2016b). QIAamp DNA Mini and Blood Mini Handbook. QIAGEN. Sample \& Assay Technologies, $5^{\text {th }}$ edn. Available from: https://www.qiagen.com/jp/resources/download.aspx?id=62a200d6-faf4469b-b50f-2b59cf738962\&lang=e (accessed 12 April 2018).

Anonymous (2018). HLA-DRB1, DQ1, DQB1 REAL-TIME PCR Genotyping Kits. DNA-Technology. Available from:

http://www.dna-technology.ru/eng/dnaproducts/reagents/ (accessed 12 April 2018).

Balandraud, N., Picard, C., Reviron, D., Landais, C., Toussirot, E., Lambert, N., Telle, E., Charpin, C., Wendling, D., Pardoux, E., Auger, I., Roudier, J. (2013). HLA-DRB1 Genotypes and the Risk of Developing Anti Citrullinated Protein Antibody (ACPA) Positive Rheumatoid Arthritis. PLOS ONE, 8 (5), e64108.

Boettiger, D.C., Kerr, S., Ditangco, R., Merati, T. P., Pham, T. T. T., Chaiwarith, R., Kiertiburanaku, S., Li, C. K. P., Kumarasamy, N., Vonthanak, S., Lee C., Kinh, N. V., Pujari, S., Wong, W. W., Kamarulzaman, A., Zhang, F., Yunihastuti, E., Choi, J. Y., Oka, S., Ng, O. T., Kantipong P., Mustafa, M., Ratanasuwan, W., Sohn, A., Law, M. (2014). Trends in first-line antiretroviral therapy in Asia: results from the TREAT Asia HIV observational database. PLoS ONE, 9 (9), e106525.

Buck, D., Cepok, S., Hoffmann, S., Grummel, V., Jochim, A., Berthele, A., Hartung, H.-P., Wassmuth, R., Hemmer, B. (2011). Influence of the HLA-DRB1 genotype on antibody development to Interferon Beta in multiple sclerosis. Arch. Neurol., 68 (4), 480-487.

Gezie, L. D., Gelaye, K. A., Worku, A. G., Ayele, T. A., Teshome, D. F. (2017). Time to immunologic recovery and determinant factors among adults who initiated ART in Felege Hiwot Referral Hospital, northwest Ethiopia. BMC Res Notes, 10, 277.

Goronzy, J. J., Matteson, E. L., Fulbright, J. W., Kenneth J. Warrington, K. J., Chang-Miller, A., Hunder, G. G., Mason, T. G., Nelson, A. M., Valente, R. M., Crowson, C. S., Erlich, H. A., Reynolds, R. L., Swee, R. G., O'Fallon, W. M., Weyan, C. M. (2004). Prognostic markers of radiographic progression in early rheumatoid arthritis. Arthritis Rheum., 50 (1), 43-54. 
Haas, D. W., Smeaton, L. M., Shafer, R. W., Robbins, G. K., Morse, G. D., Labbe, L., Wilkinson, G. R., Clifford, D. B., D’Aquila R. T., De Gruttola, V., Pollard, R. B., Merigan, T. C., Hirsch, M. S., George, A. L., Donahue, J. P., Kim, R. B. (2005). Pharmacogenetics of long-term responses to antiretroviral regimens containing Efavirenz and/or Nelfinavir: An adult aids clinical trials group study. J. Infect. Dis., 192, 1931-1942.

Julg, B., Moodley, E. S., Qi, Y., Ramduth, D., Reddy, S., Mncube, Z., Gao, X., Goulder, P. J., Detels, R., Ndung'u, T., Walker, B. D., Carrington, M. (2011). Possession of HLA class II DRB $1 * 1303$ associates with reduced viral loads in chronic HIV-1 clade C and B infection. J. Infect. Dis., 203, 803-809.

Kapitány, A., Szabó, Z., Lakos, G., Aleksza, M., Végvári, A., Soós, L., Karányi, Z., Sipka, S., Szegedi, G., Szekanecz, Z. (2008). Associations between serum anti-CCP antibody, rheumatoid factor levels and HLA-DR4 expression in Hungarian patients with rheumatoid arthritis. Israel Med. Assoc. J, 10, 32-36.

Keet, I. P. M., Tang, J., Klein, M. R., LeBlanc, S., Enger, C., Rivers, C., Apple R. J., Mann, D., Goedert, J. J., Miedema, F., Kaslow, R. A. (1999). Consistent association of HLA Class I and II and transporter gene products with progression of human immunodeficiency Virus Type 1 infection in homosexual men. J. Infect. Dis., 180, 299-309.

Keiser, O., MacPhail, P., Boulle, A., Wood, R., Schechter, M., Dabis, F., Sprinz, E., Egger, M., for the ART-LINC Collaboration of the international databases to evaluate AIDS (IeDEA) (2009). Accuracy of WHO CD4 cell count criteria for virological failure of antiretroviral therapy. Trop. Med. Int. Health, 14 (10), 1220-1225.

Langford, S. E., Ananworanich, J., Cooper, D. A. (2007). Predictors of disease progression in HIV infection: A review. AIDS Res. Ther., 4, 11.

Lucas, G. M., Chaisson, R. E., Moore, R. D. (1999). Highly active antiretroviral therapy in a large urban clinic: Risk factors for virologic failure and adverse drug reactions. Ann. Intern. Med., 131, 81-87.

Lundgren, J. D., Mocroft, A., Gatell, J. M., Ledergerber, B., Monforte, A., Hermans, F., Goebel, F.-D., Blaxhult, A., Kirk, O., Phillips, A. N., for the EuroSIDA Study Group (2002). A clinically prognostic scoring system for patients receiving highly active antiretroviral therapy: Results from the EuroSIDA study. J. Infect. Dis., 185, 178-187.

Malhotra, U., Holte, S., Dutta, S., Berrey, M. M., Delpit, E., Koelle, D. M., Sette, A., Corey, L., McElrath, M. J. (2001). Role for HLA class II molecules in HIV-1 suppression and cellular immunity following antiretroviral treatment. J. Clin. Invest., 107, 505-517.

Mallal, S., Nolan, D., Witt, C., Masel, G., Martin, A. M., Moore, C., Sayer, D., Castley, A., Mamotte, C., Maxwell, D., James, I., Christiansen, F. T. (2002). Association between the presence of HLA-B*5701, HLA-DR7, and HLA-DQ3 and hypersensitivity to HIV-1 reverse-transcriptase inhibitor abacavir. Lancet, 359, 727-732.

Mellors, J. W., Munoz, A., Giorgi, J. V., Margolick, J. B., Tassoni, C. J., Gupta, P., Kingsley, L. A., Todd, J. A., Saah, A. J., Detels, R., Phair, J. P., Rinaldo, C. P. (1997). Plasma viral load and CD4+ lymphocytes as prognostic markers of HIV-1 infection. Ann. Intern. Med., 126 (12), 946-954.

Montarroyos, R. U., Miranda-Filho, C. D., César, C. C., Souza, W. V., Lacerda, H. R., Albuquerque, M. F. P. M., Aguiar, M. F., Ximenes, R. A. A. (2014). Factors related to changes in CD4+ T-cell counts over time in patients living with HIV/AIDS: A multilevel analysis. PLoS ONE, 9 (2), e84276.

Odafe, S., Torpey, K., Khamofu, H., Ogbanufe, O., Oladele, E. A., Kuti, O., Adedokun, O., Badru, T., Okechukwu, E., Chabikuli, O. (2012). The Pattern of Attrition from an Antiretroviral Treatment Program in Nigeria. PLoS ONE, 7 (12), e51254.

Pantaleo, G., Fauci, A. S. (1996). Immunopathogenesis of HIV infection. Annu. Rev. Microbiol., 50 (1), 825-854.

Patrikar, S., Shankar, S., Kotwal, A., Basannard, D. R., Bhattie, V., Vermaf, R., Mukherj, S. (2017). Predictors of first line antiretroviral therapy failure and burden of second line antiretroviral therapy. Med. J. Armed Forces India, 73, 5-11.

Pavlos, R., Mallal, S., Phillips, E. (2012). HLA and pharmacogenetics of drug hypersensitivity. Pharmacogenomics, 13 (11), 1285-1306.

Ranasinghe, S., Cutler, S., Davis, I., Lu, R., Soghoian, D. Z., Qi, Y., Sidney, J., Kranias, G., Flanders, M. D., Lindqvist, M., Kuhl, B., Alter, G., Deeks, S. G., Walker, B. D., Gao, X., Sette, A., Carrington, M., Streeck, H. (2013). Association of HLA-DRB1-restricted CD4+ T cell responses with HIV immune control. Nat. Med., 19, 930-933.

Robbins, G. K., Daniels, B., Zheng, H., Chueh, H., Meigs, J. B., Freedberg, K. A. (2007). Predictors of antiretroviral treatment failure in an urban HIV clinic. J. Acquir. Immune Def. Syndr., 44, 30-37.

Saah, A. J., Hoover, D. R., Weng, S., Carrington, M., Mellors, J., Rinaldo, C. R., Mann, D., Apple, R., Phair, J. P., Detels, R., O'Brien, S., Enger, C., Johnson, P., Kaslow, R. A., Multicenter AIDS Cohort Study. (1998). Association of HLA profiles with early plasma viral load, CD4+ cell count and rate of progression to AIDS following acute HIV-1 infection. AIDS, 12 (16), 2107-2113.

Zanelli, E., Breedveld, F. C., de Vries, R. R. P. (2002). HLA association with autoimmune disease: A failure to protect? Rheumatology, 39, 1060-1066.

Zhu, P., Zhu, Q., Zhang, Y., Ma, X., Li, Z., Li, J., Chen, J., Luo, L., Ring, H. Z., Ring, R. Z., Su, L. (2013). ABCB1 variation and treatment response in AIDS patients: Initial results of the Henan Cohort. PLoS ONE, 8 (1), e55197.

Received 23 October 2018

Accepted in the final form 18 February 2019

\section{CILVĒKA LEIKOCĪTU ANTIGĒNU II KLASES ALĒLES IETEKMĒ ATBILDI UZ 5-7 GADUS ILGU ANTIRETROVIRĀLO TERAPIJU LATVIJAS PACIENTU GRUPĀ}

Pacientiem ar HIV-1 infekciju antiretrovirālās terapijas (ART) mērkis ir nomākt vīrusu replikāciju un nostiprināt indivīda imūno sistēmu. Viens no faktoriem, kas ir atbildīgs par ART efektivitāti, ir gēnu grupa, kuru sauc par cilvēka leikocītu antigēniem (HLA). Šì pētījuma mērkiis bija atklāt HLA II klases alēḷu ietekmi uz reakciju ilgstošas ART laikā, novērtējot tās ietekmi uz CD4 ${ }^{+}$T šūnu skaita izmaiņām, kad tiek kontrolētas vīrusu slodzes izmainas. Pētījumā tika iekḷauti 69 pacienti (17 sievietes un 52 vīrieši) vecumā no 20 līdz 50 gadiem ar HIV-1 infekciju, kuriem ART tika veikta Latvijas Infektoloğijas centrā. Vidējais novērojumu periods bija 5,7 gadi. CD4 ${ }^{+}$T šunnu skaits un vīrusu slodze tika analizēti novērošanas perioda sākumā un beigās. HLA tipizēšana tika veikta ar zemas izškirtspējas polimerāzes k̦ēdes reakciju ar sekvences specifiskiem praimeriem. Multiplās hierarhiskās lineārās regresijas analīze apstiprināja, ka HIV-1 vīrusu slodzes palielināšanās paredz $\mathrm{CD}^{+} \mathrm{T}$ šūnu skaita samazināšanos. Turklāt, HLA-DRB1*04 un HLA-DQB1*06:01 alēles papildus negatīvi ietekmēja $\mathrm{CD} 4^{+} \mathrm{T}$ šūnu skaita lìmeni. 